\title{
ON SOME RECENT POMAK WRITING ACTIVITIES IN GREECE: ETHNO-CULTURAL CONTEXT AND LINGUISTIC PECULIARITIES
}

\author{
Maria Manova \\ Humboldt University of Berlin
}

\begin{abstract}
Despite numerous attempts at codifying their language, the Pomaks in Greece, a linguistic as well as religious minority, do not generally put into writing this variety, which is considered to be a Bulgarian dialect. Up until about fifteen years ago, there was an absence of any kind of lexicographic tradition. The grammars, dictionaries etc. that appeared in Greece in the mid-1990's can be classified as "external" codifications, since most of them were made by the majority. Over the last few years, however, an increasing minority-activism has changed the situation somewhat. Some writing has begun to emerge from the community, but the variety is still far from fitting the criteria for micro-literacy, the codification of which is difficult due to the different idiolectal varieties of the language actors, which are far away from a uniform orthographical norm as well as an alphabet. However, the publications in the minority language are seen as evidence of cultural emancipation and linguistic vitality. This article deals with the issues of language and literacy among the Pomaks in Greece and presents a case study of the ethno-linguistic orientation of the currently most productive Pomak language activist's writings.
\end{abstract}

Keywords: minority languages in the Balkans, identity, language planning, written use of minority languages, lexical modernization

\section{Introduction}

The Pomaks converted to Islam during the period of Ottoman rule in the Balkans. Nowadays, there are approx. 250,000 Pomaks in Bulgaria, known as "Bulgarian Muslims". The estimated number of Pomaks in Greece is 36.000, they form a part of the indigenous, non-homogeneous group of the Greek Muslim minority (the others are Turks and a relatively small number of Roma, all of whom reside in the West Thrace District). The final separation of the Pomaks by frontiers dates back to 1919, when the area 
known at present as Western Thrace was obtained by Greece. According to the Treaty of Lausanne (1923), all Pomaks who lived in Greece were to be exchanged with Turkey as Muslims, and only the Pomaks from Western Thrace were exempted from this mandatory exchange of populations. As Bulgaria fell behind the Iron Curtain after World War II, the Greek authorities turned the mountain villages near the Bulgarian border into a restricted military zone in an effort to isolate the relatively small group of the Pomaks, who stayed in Greece, from those who lived in Bulgaria. In 1951 minority schools were introduced for all Greek Muslims, the languages of instruction of which were Greek and Turkish. In 1954 all Muslim institution names were changed into "Turkish". After the Cyprus Crisis of 1974, this policy was reversed and the label "Muslim" was reintroduced, the result of which was a "turkification" of the vast majority of Greece-Pomaks, i.e. their taking on a Turkish self-identity. Because of this as well as many other acts of oppression towards them, the community has acquired a solid Turkish national identity. The end of the Cold War, especially the fall of Communism in Bulgaria, the loosening of the tense Greek-Turkish relations, as well as the advent of globalization have allowed the Greek Pomaks to come out of their isolation. In addition, Bulgaria's admission to the European Union has also contributed to a greater liberalisation in the region because of the recent EU policy of regionalization and the stimulation of cross-border cooperation.

The language situation of the Pomaks in Greece has gained prominence beyond its local context just the last fifteen years. The international scholarly literature refers to them broadly as Slavspeaking Muslims, whereas Bulgarian dialectologists define them clearly as speakers of the Rhodopean dialects of the Bulgarian language. Their present-day linguistic situation is indeed a very complex one: they are recognized as a minority only on the basis of their Muslim religion rather than on account of their language. Most of them are fluent in their own dialects (which they call pomacki ${ }^{1}$ or Greek pomakika), in Turkish as a language of education and the hegemonic language of the Muslim minority, and in Greek as the

It is worth mentioning that the same holds for the contemporary linguistic selfidentification of some of the Pomaks in Bulgaria. Srebranov (2006) claims that a lot of Pomaks from the Chech region with a lower social status also identify their native language as Pomak on the basis of its difference from Standard Bulgarian and Standard Turkish. 
official language of the state. Because of their religion some of them know some Arabic. In order to respect the usage among the speakers, I shall refer to their first language as "Pomak". I also hope that the material to be presented further in this article provides an impetus for discussion regarding the development of literacy skills among the Pomaks in Northern Greece in their mother tongue, irrespective of how the language is being labelled. Also important to stress is that it is one of three components of a highly differentiated tri-lingual situation. Depending on the individual situation, family background or village, there is a language-shift or even language-loss for the benefit of Turkish and Greek. Some Pomaks have already abandoned their language while others are currently giving it up because they believe that it has no future and that proper knowledge of Greek and Turkish is much more important for advancement, i.e. for economic or social benefits. Thus, the forthcoming observations in this article hold only for those who still maintain the language and are even willing to negotiate a written standard of usage independent of the group's Turkish, Greek, and Bulgarian options.

\section{From "imposed" micro-literacy to writing activi- ties coming from minority members}

Well aware of the advanced "turkifikation" of the Pomaks, the Greek authorities have tried in the last fifteen years to change the direction of the policy toward the community, the basic guidelines of which have been the promotion of its culture and traditions, and, most importantly, the codification and development of a separate language, distinct from Bulgarian. The popularization and development of the minority's mother tongue, and the encouragement of the minority people to write down their own oral literature were important steps towards the re-ethnization of the Pomaks. One of the main results of the controversial language planning efforts was the publication of a Greek-Pomak dictionary in 1996, which was clearly an effort to bring out a distinctive Slavic minority that is not Bulgarian, but moreover to weaken the Turkish national identity of the Pomaks (for a critical survey of the 1990'scodifications see Ioannidou and Voss 2001). In spite of the codifications, instruction in the language of the Pomaks is far from being included in the school curriculum. Michail (2001) reports high illit- 
eracy rates amongst the community members and evaluates their language situation as "imposed trilinguism". All in all, the hitherto language policy of the Greek state can be characterized as catastrophic. Moreover, on the Balkans, "forms of micro-literacy occur as an intervention by the majority to guide ethno-political orientations" (Voss 2006: 328). It will never be known if the Greek authorities who tried to create a micro-literacy for the Pomaks were familiar with the concept of the "Slavic microlanguages" developed by Dulièenko $(1981,1994)$, which was an attempt at trying to systemize the literal or standard languages in developmental stages of Slav-speaking minority groups. Such groups, who do not have their own country, live as language-island minorities or borderland minorities. In addition, these groups did not take part in shaping the present standard languages which are their natural umbrella languages, but, for certain historical or political reasons, were unable to fulfil that function. Instead, they constructed their own written standards based on the local speech with interference from the language(s) in their immediate environment. Although, it is still a matter of debate whether such varieties should be classified as micro-languages, the so-called Burgenland-Croatian and BanatBulgarian ${ }^{2}$, for instance, are being treated as South-Slavic microlanguages. This concept, however, (still) does not hold for the various dialects spoken by the Pomaks because theirs do not fit the criteria for standard languages. Since it has been argued that "all Balkan Muslims strictly reject identifications offered by the majority that regard their mother tongue as being essentially a marker of ethno-national belonging" (Voss 2006: 328), and their identity is based on religion and not on language, the vast majority of the Pomaks have strongly disapproved of the language planning measures of the Greek authorities trying to create a micro-literacy for the group. Thus, the present day ethno-linguistic identity of the Pomaks is quite a complex one. We can distinguish between two main opinions on self-identity: currently there is a tension between the pro-Turkish oriented Pomaks and those who insist on a separate Pomak identity. The latter are very active in the writing-down

2 As also noted by others, as for instance by Srebranov (2006), the speakers of Banat-Bulgarian in Romania clearly define themselves as Bulgarian-speakers, and as being Bulgarian by origin in spite of their Catholicism and their living in the multi-ethnic Banat region in Romania. The Greek Pomaks, however, mostly reject any affiliation with the Bulgarian language and nation. 
process of their mother tongue, while those who tend to see themselves as Turks strongly disapprove of it. Yet there is not sufficient data on how many Pomaks are able to put down in writing their first language and also on the attitudes of ordinary native speakers towards such a process.

\section{Notations emerged from active community members}

Concerning the process of putting speech into writing, the article has made use of such expressions as "write down" or "notate". However, research conducted in the German language on orality (German "Mündlichkeit") and literacy (German "Schriftlichkeit"), as for instance Raible (1998a: 174-178), differentiates between "Verschriftung" ("the mere writing down of what is stated orally") and "Verschriftlichung" ("the conquest of the cognitive/conceptual realm", "a cultural process with enormous breadth"). Raible (1998b: 170) further defines "Verschriftlichung" as a "development of a culture into a writing culture", "a process of longue durée". Ehler and Schäfer (1998) suggest the following equivalents for the aforementioned German terms: scripting for "Verschriftung" and textualization for "Verschriftlichung". It must be also stressed that while textualization tends to play less of a role in cultures' self-perception, scripting (in the sense of the use of various orthographies) is assigned significantly greater importance (Ehler and Schaefer 1998: 8). Indeed this statement seems to find confirmation when dealing with the latest written language use of Pomaks from Greece.

Although sporadic and even chaotic, the proliferation of writings produced by the minority combined with political factors, i.e. the Greek support for the Pomak culture, has led to some increase of the micro-literacy (in the sense of Dulièenko). Actually, at first glance, these independent writing activities of the Pomaks fit quite well into the framework of the previous cultural politics of the Greek authorities, and thus into the traditions of the 1990s codifications. But, since the communication in this variety is mostly oral and its written tradition is a very short and a very controversial one, the people putting it into writing have to face some challenges, such as choice of script and lexical enrichment. The current notations of the Pomak language reflect idiolectal language use, and they vary in 
their linguistic and orthographic orientation. At this point, a unified writing system is unforeseeable. There are two scripts in use: the Greek one and a modified Latin one (following the Turkish or even the English orthography). There is also evidence that a dictionary of the Pomak language printed in the Cyrillic alphabet is under construction. Even so, coherent texts in Cyrillic are still absent and field research conducted in the villages around Xanthi in April and September 2009 showed that the vast majority of the subjects were not familiar with the Cyrillic alphabet.

Currently there are two Pomak newspapers - the first of them, named "Zagalisa" has been in circulation since 1997, and is issued by the Pomak Research Center in Komotini. Firstly, only the Greek alphabet was used to write the articles. For the small lessons in the Pomak language, a modified Latin alphabet was used. At this time, short texts written in the Greek alphabet have been appearing, the main characteristic of which is that Slavic sibilants $/ \check{S} /$ and $/ \check{z} /$ are expressed via doubling of Greek graphemes, i.e. ' $\sigma \sigma$ ' for $/ \check{s} /$, and ' $\zeta \zeta$ ' for /žl. In the last issues of "Zagalissa" the texts written in the Greek script are quite sporadic, which is why this article focuses on recent text productions of one language activist who has been writing continuously in his first language variety for the last few years. In Xanthi (approx. 2/3 of the Pomaks in Greece reside in the villages around this town) he issues the other newspaper of the Pomaks in Greece, named "Natpresh" (meaning forward; ahead!) and also other publications, as for instance a book called "That's how the Pomaks live" 3 and a leaflet on an examination for the early detection of cancer foreseen for the Pomak women. All these texts, written by Sebaidin Karahodza, are printed bilingually, in Pomak and Greek. It might be either because even some native speakers would have difficulties in reading or understanding his variety, or to make these writings available also for Greeks. Such activities show an increased awareness of the potential of the mother tongue and bring about the question of future perspectives for the development of literacy skills for the Pomaks. Karahodza's short articles are valuable examples of authentic writing on current topics in the minority community, among others the multi-optional identity of the Pomaks. The text presented below is evidence of the author's linguistic creativity and also of some lexicographical and orthographical problems he faces. It can

3 His credo in the preface: "All of us can write everything in our Pomak language, we only have to want this really". 
be characterised through Greek- and even English-borrowed features, i.e. word-stress marking as in the Greek orthography and the digraphs as in the English orthography ('sh' and 'ch' for representing the Slavic phonemes / $\check{s} /$ and $/ \check{c} /$ ), which is the more striking of the two borrowed orthographic features. Thus, he ignores the resources of the Roman-based Turkish alphabet, 'ş' and 'ç', with which he is surely familiar because Turkish has been an essential part of every Pomak's school curriculum. Not to mention that the use of single Turkish letters would be more economical than the use of English digraphs. On the other hand, one other letter from the modified Turkish Roman alphabet is used, namely ' ï'. It seems that the occurrence of the so-called schwa-phoneme, which is generally considered to be a common feature of all Balkan languages, is graphically represented through the letter ' $i$ '. The following text demonstrates the current lexical and orthographical distance of this scripted variety from the Cyrillic-written Bulgarian as its natural umbrella language (the bold marked words are of Turkish origin):

\section{ÍSHTEME SERBEZLÍKA}

Faf Iskéche i faf Gümüjûne zhïvót ad yûsbin kishí nagóre müslümáne. Anní gi zavót Túrtse I drúzi gi zavót Pomátse. Za móne ye ne právo da izlízot adín dvamína I da dúmet za yûsbin kasha insane, da kázavot tíye kakvíso isézi insan I ad kadé so dashlíli itúy. Právoto mu ye sâkotri da íma háka da si dúmi yálnïs za tóga, da si vârava kaknána íshte toy i da ye kakvófna toy íshte. Ne drúzi da mu kázavot kakvófye toy. Za móne sâkotry íma háka da víka óti ye Túrchin íli óti ye Pomáchin, vrítsi so Alláhavi insán da so Túrtsi da so Pomátsi. Trâbava níkotroga da go ye ne strah, trâbava vrítsi da ímot serbezlíka da vâravot kaknána íshtot i da so chûdet kákna íshtot. Ya gi insánase na délem na Túrtse na Pomátse i na Urúme alá gi délem na húbave i na parátse. Ya som Pomáchin alá móchom da ímom Túrtse i Urúme arkadáshe. Agî mi badín móne stóri húbgo prepaznávom go i na adbávemiso kakvófye chîyen mi ye stóril húbavo no. Ne ye hich parátiko da ye badín Túrchin íli da íshte da ye Túrchin alá ye yátse parátiko da si ne Túrchin, da na íshtesh da si Túrchin i drúzi da móchet da to stóret zórlo Túrchina. Vrítsi trâbava da so chûdime isîy, da zhïvéme isîy alá znom ta so ne vrítsi isîy. 


\section{We want freedom (of expression)}

In Xanthi and in Komotini live more than one hundred thousand Muslims. Some call them Turks and other call them Pomaks. To me, it's not right that one or two persons dictate to one hundred people what kind of people they are and where they came from. The correct attitude would be that everybody should have the right to speak only about himself, to believe what he wants and to be what he wants, and not that others tell him what he is. For me, everybody has the right to say that he is a Turk or a Pomak, all of them are Allah's people, be they Turks or Pomaks. Nobody should be afraid, all should have the freedom to believe whatever they want and to think whatever they want. I do not divide the people into Turks and Pomaks, but into good and bad. I am a Pomak, but I can have Turkish and Greek friends. It is not bad at all if someone is a Turk or wants to be a Turk, but it is very bad, if you are not a Turk, if you don't want to be a Turk and some other people try to make you a Turk by force. We should all think like this and act accordingly, live like this, but I know that we arn't all like this.

As we can see, there is quite a lot of Turkish-derived lexemes. Even Pomaks who do not really know Turkish use a lot of Turkish words to fill nomination gaps in their first language, since for certain historical or cultural reasons there is a massive Turkish lexical influence on their variety. The following content words ${ }^{4}$ incorporated into the text are of Turkish origin: serbezlíka (serbestlik freedom, ease), yûsbin (yüz bin - hundred thousand), kishí (kişi person), háka (hak - right), insan (insan - human; people), yálnïs (yalnız - only), arkadáshe (arkadaş - friend), hich (hiç - only), zórlo (zor-problem, difficulty). For the sake of completeness, it should be mentioned that since the Ottoman-Turkish has left deep traces in the lexicon of all Balkan languages, there were a lot of Turkish loan words in Bulgarian. However, the composition of the

4 Lexical units that convey meaning, i.e. content words are often being borrowed than function words (express grammatical relationships with other words in the sentence). It should be noted that in an another article of his, the author incorporates also function words from Greek, such as the conjunction para (parav - than). 
new Bulgarian literary language has proven itself to be downright intolerant of turkisms, which have been systematically replaced with Russian or Old Church Slavonic words. Nevertheless, a large quantity of the turkisms have not been able to be displaced from the language, and are still vital in the dialects or in every-day speech. In the language use of the Pomaks in Greece, we can find Ottoman-Turkish words which have already been removed from present-day Bulgarian (e.g. insan - people), but also from the modern Turkish: e.g. tayyare in the form tiuhara (airplane), found in the Pomak-Greek dictionary of Theocharidis (1996: 628). Pomaks generally see Turkish words as an integrative part of their Muslim culture. The attempt to correlate identity issues with lexical issues seems a bit odd, but it appears as though the multi-optional identity of small Muslim groups like the Greek Pomaks can be seen generally through three main options in lexical modernization of their dialects. The borrowing of Turkish lexemes, e.g. hükümet (government), sms mühtûp (sms), shows their allegiance to the largest group of the Greek Muslims. Greek loanwords, such as taftotita (passport; identity card) or astinomia (police) are inevitable because Greek is the language of the state they live in. However, it turns out in the end that even rare, lexical modernization on a Slavic basis is also possible, as for example the Slavic word preduma (foreword, preface) coined by Karahodza according to the Greek

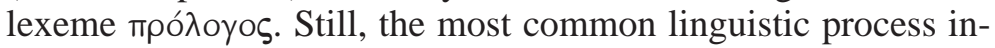
volved in the lexical modernization of the dialects spoken by the Pomaks is the extensive borrowing from both Turkish and Greek, while language activists of some Slavic minority languages, as for instance of the lower Sorbian, try to use persistently the language's own resources to fill nominal gaps. Lexical items are also borrowed from English as well. Thus, the issue of linguistic purism does not play a significant role in the lexical expansion of the Pomak dialects, since they have been strongly affected by diglossia and code-switching. Language material, as for instance numerals, has been assimilated from the Turkish language into the speech of the Pomaks. This can also be seen in the following announcement which reflects every-day speech on trivial topics, and where a Turkish numeral (beșinci - fifth) has been written down according to the principles of English orthography as beshinjí (the digraphs 'sh' for the 's' and the single letter ' $\mathrm{j}$ ' for the Turkish 'c'). Its seems to be that all above mentioned Turkish words are established loanwords,

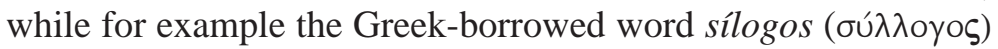


can be handled as a nonce borrowing giving some evidence of the lexical acculturation towards the Greek language.

\section{POMÁTSKÏY VÉCHER}

Faf Sóboto 19 Lióshko 2008 i sahát 17:00 faf hotel AGRIANÍ na beshinjí klm Iskéche Shahín Iskécheskïyen Pomátskïy sílogos she právi Pomátska vécherä i zhíne so itám she mózhot da nakúset mlógo Pomátskï yetá i da chûyet mlógo Pomátskï pésne. Châkame vo vritsâh. Vlízanye serbés

\section{Pomak evening}

On Saturday, 19 April 2008, at 5:00 p.m. in the hotel "Agriani", at the fifth kilometre from Xanthi to Echinos, the Pomak association of Xanthi will host a Pomak evening and all people can try a lot of different Pomak meals and hear many Pomak songs. We are waiting for all of you.

Free entry

To sum up, the linguistic peculiarities of the currently most active community member's writings are that the resources of the English (i.e. "international") orthography are being employed in an effort to start and practice a written language use, distinguishing the group from the "Turkish" - as well as from the "Bulgarian" option. Thus, these activities fit into the previous efforts of the Greek authorities towards establishing a distinct Pomak identity, since, as has been shown by Fergusson (1978), the achieving of literacy hardens ethnic group identity. This writing also shows us the "permitted" positive attitude toward the language, since such small announcements on everyday occasions, not to mention newspaper articles, would have been impossible two decades ago and are still written mostly in Greek and Turkish and almost never in the language spoken by the Greek Pomaks. Nevertheless, these developments confirm that scripting, in the sense of the use of various orthographies, is assigned great importance. It remains to be seen whether the use of the uneconomical, and inadequate to reproduce the Slavic phonology Greek script with which all of the Pomaks are familiar, will prevail over the Latin script. Last but not least, whether the Cyrillic alphabet will have a chance is also in 
question, since the Bulgarian option for the Pomaks in Greece has become slightly more attractive for the group as well as for the Greek authorities.

\section{Address:}

Maria Manova

Danneckerstr. 10

10245 Berlin

Germany

E-mail:maria.manova@slawistik.hu-berlin.de

\section{References}

Duličenko, А. (1981) Славянские литературные микроязыки. Tallinn: Valgus. Duličenko, A. (1994) "Kleinschriftsprachen in der slawischen Sprachenwelt". Zeitschrift für Slawistik 39, 4, 560-567.

Ehler, C. and U. Schaefer (1998). Verschriftung und Verschriftlichung. Aspekte des Medienwechsels in verschiedenen Kulturen und Epochen. Tübingen: Narr.

Ferguson, C. A. (1978) "Patterns of literacy in multilingual situations". In J. E. Alatis, ed. International dimensions of bilingual education, 582-590. Washington D.C.: Georgetown University.

Ioannidou, A. and C. Voss (2001) "Kodifizierungsversuche des Pomakischen und ihre ethno- politische Dimension". Die Welt der Slaven 46, 223-250.

Michail, D. (2001) "The imposed trilingualism and the making of illiteracy: the case of the Pomaks in the mountainous area of Xanthi”. Peri Thrakis 2, 271287.

Raible, W. (1998a) Medienwechsel. Erträge aus zwölf Jahren Forschung zum Thema Mündlichkeit und Schriftlichkeit. Tübingen: Narr.

Raible, W. (1998b) "Die Anfänge der volkssprachlichen Schriftkultur in der Romania oder: die Eroberung konzeptueller Räume". In C. Ehler and U. Schaefer, eds. Verschriftung und Verschriftlichung. Aspekte des Medienwechsels in verschiedenen Kulturen und Epochen, 156-173). Tübingen: Narr.

Srebranov, R. (2006) “Bulgarian Muslims from the Chech region”. International Journal of the Sociology of Language 179, 131-143.

Theocharidis, P. (1996). Поцакоє $\lambda \lambda \eta \nu$ เкó $\Lambda \varepsilon \xi$ ıкó. Thessaloniki.

Voss, C. (2006) "Toward the comparability of Slav-speaking Balkan Muslims in the light of the microlanguage concept". In A. Dulièenko and S. Gustavsson, eds. Slavonic literary micro-languages and language contact, 326- 
339. Tartu: Tartu University Press.

Voss, C. (2007) "Language and ethnicity among the Pomaks in Western Thrace". In J. Tiševa, ed. Bulgarian islands on the linguistic map of the Balkans, 76-86. Sofia: Figura.

Voss, C. (2007) "Language ideology between self-identification and ascription among the Slavic-speakers in Greek Macedonia and Thrace”. In K. Steinke and C. Voss, eds. Die Pomaken in Griechenland und Bulgarien als Musterfall balkanischer Grenzminderheiten. The Pomaks in Greece and Bulgaria - a model case for borderland minorities in the Balkans, 177-192. München: Otto Sagner.

\begin{abstract}
Kokkuvõte. Maria Manova: Hiljutisest Pomaki murde kirjutamisest Kreekas: etnokultuuriline kontekst ja keelelise omapärad. Vaatamata arvukatele keele normeerimise katsetele, pole pomakid, kes on Kreekas nii keeleline kui ka religioosne vähemus, suutnud laialdasemalt kasutusele võtta seda kirjavarianti, mida peetakse Bulgaaria murdeks. Veel umbes 15 aastat tagasi puudus igasugune leksikograafiline traditsioon. Kreekas 1990ndate keskel ilmunud grammatikaid, sõnaraamatuid jne võib klassifitseerida "väliste" normeerijatena, kuna suurema osa neist oli teinud enamusrahvus. Viimastel aastatel on suurenenud vähemusaktiivsus siiski olukorda mõnevõrra muutnud. Kogukonnas on hakanud levima kirjutised, kuid see varieteet ei vasta endiselt vähemuskeele kirjaoskuse nõuetele, mille normeerimine on raske erinevate idiolektiliste variatsioonide tõttu, millel puudub ühtne ortograafia ja ka tähestik. Siiski on vähemuskeelsed publikatsioonid tõend kultuurilisest iseseisvumisest ja keelelisest vitaalsusest. Käesolev artikkel käsitleb Kreekas elavate pomakkide keele- ja kirjaoskuse küsimusi ning esitleb hetkel kõige produktiivsemate pomaki keele aktivistide etniliskeelelise orientatsiooni analüüsitulemusi.
\end{abstract}

Märksõnad: Balkani vähemuskeeled, identiteet, keelekorraldus, vähemuskeelte kirjalik kasutus, sõnavaraline kaasajastamine 